\title{
PERUBAHAN RESPONS RESEPTOR ADRENERGIK- $\beta$ DAN MUSKARINIK DI OTOT POLOS SALURAN NAFAS TIKUS WISTAR PADA PROSES PENUAAN
}

\section{ALTERATION OF THE $\beta$-ADRENERGIC AND MUSCARINIC RECEPTORS RESPONSIVENESS IN AIRWAY SMOOTH MUSCLE OF WISTAR RAT DURING AGING}

\author{
Setyawati Soeharto Karyono \\ Laboratorium Farmakologi Fakultas Kedokteran Universitas Brawijaya Malang
}

\begin{abstract}
Aging process is a unique and complex process which could not be prevented. Many physiologic changes could be seen for adaptation during aging process. These changes influence pharmacodynamic and pharmacokinetic of drug and cause alteration of drug effect. Pharmacodynamic changes are caused by alteration of drug receptor. The objective of this study was to evaluate the influence of aging on $\beta$-adrenergic and muscarinic receptors function in rat airway smooth muscle. Isolated tracheal ring preparation and lung strip were used to examine relaxation response to isoprenaline ( $\beta$-adrenergic agonist) and contraction response to metacholine (muscarinic agonist). Tracheal ring preparations and lung strip were taken from young (4-5 weeks), adult (4-6 months) and old (24-26 months) wistar rats.. The results showed that the $\beta$ adrenergic receptor response significantly decreased $(p<0,05)$ in tracheal ring and lung strip from aged rat as compared to young and adult rat.. This study has also demonstrated that muscarinic receptor responsiveness of lung strip significantly increased $(p<0,05)$ in aged rat as compared to young and adult rat.. These results suggested that the alteration of $\beta$-adrenergic and muscarinic receptor function in airway smooth muscle caused by homolog and heterolog receptor regulation during aging. Further studies is needed to discover the definite mechanism of receptor regulation in aging.
\end{abstract}

Key words: aging - $\beta$-adrenergic receptors - muscarinic receptors - airways

\section{PENDAHULUAN}

Pada usia lanjut umumnya terjadi berbagai perubahan fisiologik yang meliputi perubahan fisik maupun psikologik. Perubahan fisiologi selama proses penuaan akan menyebabkan perubahan respons organ / sel terhadap stimuli endogen dan eksogen (1). Perubahan respons terhadap stimuli eksogen salah satunya adalah perubahan respons terhadap obat, sehingga terjadi perubahan efek obat yang dapat menyebabkan terapi tidak adekuat dan/ atau mudah timbul efek samping. Pada umumnya perubahan efek obat disebabkan karena perubahan farmakokinetik dan/ atau farmakodinamik obat. Perubahan farmakokinetik biasanya karena perubahan struktur dan fungsi dari berbagai organ yang berperan pada proses absorpsi, distribusi, metabolisme dan ekskresi obat, sehingga kadar obat bebas yang beredar di dalam darah dan di tempat kerjanya berubah dapat meningkat atau menurun. Perubahan farmakodinamik pada umumnya karena perubahan sel target atau reseptor sebagai tempat kerja obat $(2,3)$. Perubahan pada tingkat reseptor ini bervariasi di berbagai organ sisitem. Ter-

Jurnal Kedokteran Brawijaya, Vol. XXII, No. 3, Desember 2006 Korespondensi: Setyawati S Karyono; Laboratorium Farmakologi Fakultas Kedokteran Unibraw Malang; Jl. Veteran Malang: 0341-580993; email: wati@fk.unibraw.ac.id jadi peningkatan respons beberapa reseptor di SSP $(4,5)$. Dapat pula terjadi penurunan respons reseptor seperti pada adrenergik- $\beta 1$ di jantung $(6,7,8)$, adrenergik- $\beta_{2}$ di pembuluh darah (9), adrenergik- $\alpha$ di atria (10), adrenergik- $\alpha_{2}$ pre-sinap (11), reseptor histamin $\mathrm{H}_{1}$ di ileum (5) dan reseptor muskarinik $\mathrm{M}_{2}$ di jantung $(8,12)$. Beberapa fakta tersebut menunjukkan bahwa pada proses penuaan terjadi perubahan respons reseptor yang bervariasi yang akan mengakibatkan perubahan fisiologis berbagai organ. Mekanisme pada proses penuaan merupakan mekanisme komplek yang tidak disebabkan oleh faktor tunggal, melainkan multifaktorial. Proses penuaan pada sel sebagian besar dipengaruhi faktor genetik dan dimodulasi oleh interaksi berbagai faktor intrinsik dan ekstrinsik misalnya lingkungan sel $(1,13,14)$.

Saluran nafas merupakan organ vital yang juga mengalami penuaan. Sesuai dengan fungsinya menyalurkan udara ke alveoli, maka selama proses penuaan saluran nafas selalu terpapar dengan udara/ lingkungan luar termasuk di dalamnya bahan-bahan xenobiotik seperti polutan, debu, bakteri, asap rokok yang sangat potensial menimbulkan reaksi inflamasi. Pada suatu studi dilaporkan bahwa mediator inflamasi antara lain IL-1 $\beta$ dan TNF- $\alpha$ terbukti dapat menurunkan respons reseptor adrenergik- $\beta$ di otot polos saluran nafas (15). Selain itu pada penuaan terjadi peningkatan reactive oxygen species baik yang berasal dari hasil metabolisme normal ataupun karena paparan xeno- 
biotik yang terus menerus sepanjang hidup akan menyebabkan peningkatan lipid peroksid di membran sel sehingga fungsi reseptor transmembran terganggu (16). Pengaruh penuaan di saluran nafas tersebut dapat diduga juga akan menimbulkan perubahan pada reseptor-reseptor yang tersebar di saluran nafas.

Kontraktilitas saluran nafas diperlukan untuk menyalurkan udara dan ini dikontrol oleh persyarafan otonomik dan berbagai hormon lokal (mediator). Dari sistim saraf otonomik dikeluarkan nerotransmiter norepinefrin dan asetilkholin yang bekerja pada reseptornya yaitu reseptor adrenergik dan kholinergik muskarinik. Kedua reseptor ini mempunyai peran penting dalam mengatur kontraktilitas saluran nafas sehingga terjadi keseimbangan antara relaksasi dan kontraksi (17) Dengan demikian pengaruh penuaan terhadap reseptor adrenergik- $\beta$ di saluran nafas yang meliputi trakhea dan paru perlu dikaji lebih lanjut. Seiring dengan itu perlu pula diketahui perubahan reseptor muskarinik di saluran nafas karena kedua reseptor inilah yang berperan dalam regulasi kontraktilitas otot polos saluran nafas dan sekaligus adanya mekanisme cross-talk yang terjadi antara kedua reseptor tersebut $(17,18)$.

Penelitian ini bertujuan untuk membuktikan bahwa terjadi perubahan respons reseptor adrenergik- $\beta$ dan muskarinik pada otot polos trakhea dan sayatan paru tikus yang mengalami penuaan.

\section{METODE}

Untuk membuktikan pengaruh penuaan terhadap perubahan respons reseptor adrenergik dan muskarinik pada saluran nafas, maka dilakukan percobaan dengan metode isolated organ. Organ saluran nafas yang digunakan pada percobaan ini adalah rangkaian cincin trakhea dan sayatan paru dari tikus umur muda (4-5 minggu), dewasa (5-6 bulan) dan tua (24-26 bulan). Setelah preparasi, cincin trakhea dan sayatan paru segera dimasukkan ke dalam organ bath yang berisi larutan Kreb's dengan temperatur 35-370 $\mathrm{C}$ dan terus menerus dialiri gas karbogen, selanjutnya diinkubasi dulu selama 1-2 jam untuk adaptasi sebelum dilakukan percobaan. Selama inkubasi larutan Kreb's selalu diganti baru setiap 10 menit dan temperatur pada organ bath tetap dipertahankan stabil $\left(35-37^{\circ} \mathrm{C}\right)$.

Respons reseptor adrenergik- $\beta$ berupa relaksasi terjadi setelah pemberian agonis adrenergik- $\beta$ (isoprenalin) yang terlebih dahulu dilakukan pre kontraksi dengan metakholin $10^{-7} \mathrm{M}$. Sedang respons reseptor muskarinik berupa kontraksi terjadi setelah pemberian agonis muskarinik (metakholin). Dosis yang digunakan adalah dosis kumulatif mulai dosis minimum sampai dosis maksimum. Respons diteruskan melalui "isotonic transducer" dan direkam pada rekorder "McLab Computer". Gambar hasil rekaman berupa relaksasi ataupun kontraksi dapat diukur besarnya dan dibuat kurva dosis respon untuk penghitungan ED50 (dosis yang menimbulkan $50 \%$ respons), yang menggambarkan kepekaan reseptor dan $\mathrm{pD}_{2}$ yang menggambarkan afinitas reseptor terhadap agonisnya $\left(\mathrm{pD}_{2}=-\log \mathrm{Kd}=-\log \mathrm{ED50}\right)$. Efek maksimum (Emaks) isoprenalin diukur dari prosentase relaksasi maksimum terhadap prekontraksi dan Emaks metakholin diukur dari besar kontraksi yang ditimbulkan. Emaks dapat untuk "memperkirakan" jumlah reseptor yang mampu menimbulkan efek maksimum dan menggambarkan mekanisme sinyal transduksi (18). Waktu maksimum (Tmaks) diukur dari waktu yang diperlukan mencapai efek maksimum.

Data yang diperoleh adalah data kualitatif dan kuantitatif. Data kualitatif berupa pengamatan respons organ terhadap stimuli agonis dan pergeseran kurva dosis respons, sedangkan kuantitatif didapat dari pengukuran efek maksimum (Emaks), waktu maksimum (Tmaks), ED50, dan $\mathrm{pD}_{2}$. Untuk mengetahui perbedaan data kuantitatif pada umur muda, dewasa dan tua dilakukan analisa dengan Multivariat anova (manova).

\section{HASIL PENELITIAN}

\section{Respons reseptor adrenergik- $\beta$}

Hasil percobaan menunjukkan penurunan respons relaksasi otot polos trakhea terhadap stimuli isoprenalin pada trakhea dan paru tikus tua dibanding muda dan dewasa (Tabel 1 dan 2).

Tabel 1.Dosis isoprenalin yang menimbulkan relaksasi minimum dan maksimum pada trakhea tikus muda, dewasa dan tua.

\begin{tabular}{lccc}
\hline Isoprenalin & Muda & Dewasa & Tua \\
\hline Dosis minimum & {$\left[10^{-9}\right] \mathrm{M}$} & {$\left[10^{-8}\right] \mathrm{M}$} & {$\left[3.10^{-8}\right] \mathrm{M}$} \\
Dosis maksimum & {$\left[3^{\left.-10^{-5}\right] \mathrm{M}}\right.$} & {$\left[3.10^{-4}\right] \mathrm{M}$} & {$\left[10^{-3}\right] \mathrm{M}$} \\
\hline
\end{tabular}

Keterangan: Untuk menimbulkan respons relaksasi yang sama, trakhea tikus tua memerlukan dosis isoprenalin yang lebih besar dari pada trakhea tikus muda dan dewasa.

Tabel 2.Dosis isoprenalin yang menimbulkan relaksasi minimum dan maksimum pada sayatan paru tikus muda, dewasa dan tua.

\begin{tabular}{lccc}
\hline Isoprenalin & Muda & Dewasa & Tua \\
\hline Dosis minimum & {$\left[10^{-9}\right] \mathrm{M}$} & {$\left[3.10^{-9}\right] \mathrm{M}$} & {$\left[10^{-8}\right] \mathrm{M}$} \\
Dosis maksimum & {$\left[10^{-5}\right] \mathrm{M}$} & {$\left[3.10^{-5}\right] \mathrm{M}$} & {$\left[10^{-4}\right] \mathrm{M}$} \\
\hline
\end{tabular}

Keterangan:Untuk menimbulkan respons relaksasi yang sama, sayatan paru tikus tua memerlukan dosis isoprenalin yang lebih besar dari pada tikus muda dan dewasa.

Penurunan respon relaksasi trakea terhadap isoprenalin digambarkan dengan adanya pergeseran kurva tikus tua ke kanan seperti ditunjukkan pada Gambar 1. 


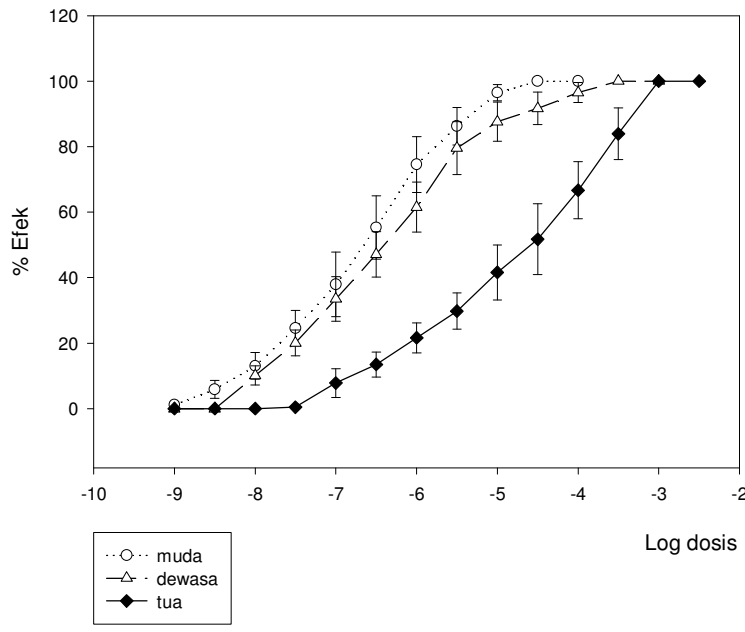

Keterangan:Pergeseran kurva trakhea tikus tua ke kanan menunjukkan penurunan respons trakhea tikus tua terhadap isoprenalin (tua $<$ dewasa $<$ muda).

Gambar 1.Kurva dosis respons isoprenalin pada otot polos trakhea tikus muda, dewasa dan tua.

Hasil percobaan pada sayatan paru tikus mempunyai pola yang sama dengan hasil pada trakhea yaitu terjadi penurunan respons relaksasi paru terhadap stimuli agonis reseptor adrenergik- $\beta$ pada paru tikus tua dibanding muda dan dewasa. Hal ini berdasar pada peningkatan dosis minimum dan maksimum pada sayatan paru tua dan pergeseran kurva paru tua ke kanan pada gambar kurva dosis respons isoprenalin (gambar tidak dicantumkan).

\section{Respons reseptor muskarinik}

Didapatkan penurunan kepekaan (ED50) dan afinitas $\left(\mathrm{pD}_{2}\right)$ reseptor adrenergik- $\beta$ terhadap isoprenalin pada trakhea dan paru tikus tua dibanding dewasa dan muda secara bermakna $(p<0,05)$, sedangkan antara dewasa dan muda penurunan ini tidak bermakna. Analisa korelasi menunjukkan adanya hubungan linier yang signifikan antara peningkatan umur dengan peningkatan ED50 dan penurunan $\mathrm{pD}_{2}$, isoprenalin $(r=-0,81 ; p=0,00)$. Data kuantitatif lain ditunjukkan oleh Emaks dan Tmaks, yaitu terdapat penurunan Emaks dan perpanjangan waktu Tmaks baik pada trakhea maupun pada sayatan paru tikus tua dibanding dewasa dan muda, tetapi data ini tidak bermakna kecuali pada perpanjangan Tmaks trakhea tua (Tabel 3 dan 4).

Hasil percobaan menunjukkan peningkatan respon kontraksi otot polos trakhea dan paru terhadap metakholin pada tikus tua dibanding muda dan dewasa (Tabel 5 dan 6)

Tabel 3.Rerata efek relaksasi maksimum, waktu maksimum, ED50 dan pD2 isoprenalin pada trakhea tikus muda, dewasa dan tua.

\begin{tabular}{lcccc}
\hline & Muda $(\mathrm{n}=7)$ & Dewasa $(\mathrm{n}=7)$ & Tua $(\mathrm{n}=7)$ & sig \\
\hline Emaks & $96,4 \pm 13,49$ & $76,89 \pm 5,25$ & $76,84 \pm 6,85$ & 0,192 \\
Tmaks (mnt) & $27 \pm 1,82$ & $32,86 \pm 3,21$ & $43,33^{*} \pm 1,60$ & 0,001 \\
& & & & $(\mathrm{r}=0,72)$ \\
ED50 [M] & $4,07.10^{-7} \pm 1,57 \cdot 10^{-7}$ & $5,59.10^{-7} \pm 2,66 \cdot 10^{-7}$ & $2,53 \cdot 10^{-5^{*} \pm 1,42 \cdot 10^{-5}}$ & 0,048 \\
$\mathrm{pD}_{2}$ & $6,66 \pm 0,21$ & $6,57 \pm 0,21$ & $4,90^{*} \pm 0,22$ & 0,000 \\
& & & & $(\mathrm{r}=0,81)$
\end{tabular}

MANOVA, uji Wilk's lambda $p=0,001$

Tabel 4. Rerata efek relaksasi maksimum, waktu maksimum, ED50 dan $\mathrm{pD}_{2}$ isoprenalin pada sayatan paru tikus muda, dewasa dan tua.

\begin{tabular}{lcccc}
\hline & Muda $(\mathrm{n}=7)$ & Dewasa $(\mathrm{n}=7)$ & Tua $(\mathrm{n}=7)$ & sig \\
\hline Emaks & $134,56 \pm 21,55$ & $91,72 \pm 6,51$ & $78,92 \pm 11,75$ & 0,057 \\
Tmaks (mnt) & $25,42 \pm 1,39$ & $25,28 \pm 0,85$ & $27,28 \pm 1,48$ & 0,530 \\
ED50 [M] & $8,52.10^{-8} \pm 3,84.10^{-8}$ & $4,25.10^{-8} \pm 0,55.10^{-8}$ & $2,15.10^{-7} \pm 0,83.10^{-7}$ & 0,081 \\
$\mathrm{pD}_{2}$ & $7,33 \pm 0,19$ & $7,39 \pm 0,05$ & $6,86 \pm 0,15$ & 0,057 \\
& & & & $(\mathrm{r}=0,5)$ \\
\hline
\end{tabular}


Tabel 5.Dosis metakholin yang menimbulkan kontraksi minimum dan maksimum pada trakhea tikus muda, dewasa dan tua.

\begin{tabular}{lccc}
\hline Metakholin & Muda & Dewasa & Tua \\
\hline Dosis minimum & {$\left[10^{-8}\right] \mathrm{M}$} & {$\left[10^{-8}\right] \mathrm{M}$} & {$\left[10^{-9}\right] \mathrm{M}$} \\
Dosis maksimum & {$\left[3.10^{-4}\right] \mathrm{M}$} & {$\left[10^{-4} \mathrm{M}\right.$} & {$\left[3.10^{-5}\right] \mathrm{M}$} \\
\hline
\end{tabular}

Keterangan:Untuk menimbulkan respons kontraksi minimum dan maksimum, trakhea tikus tua memerlukan dosis metakholin yang lebih rendah dari pada dewasa dan muda.

Tabel 6.Dosis metakholin yang menimbulkan kontraksi minimum dan maksimum pada sayatan paru tikus muda, dewasa dan tua

\begin{tabular}{lccc}
\hline Metakholin & Muda & Dewasa & Tua \\
\hline Dosis minimum & {$\left[10^{-8}\right] \mathrm{M}$} & {$\left[10^{-8}\right] \mathrm{M}$} & {$\left[10^{-9}\right] \mathrm{M}$} \\
Dosis maksimum & {$\left[10^{-3}\right] \mathrm{M}$} & {$\left[10^{-3}\right] \mathrm{M}$} & {$\left[10^{-4}\right] \mathrm{M}$} \\
\hline
\end{tabular}

Keterangan:Efek minimum dan efek maksimum metakholin pada paru tikus tua terjadi pada dosis yang lebih rendah dibanding dewasa dan muda.

Hasil percobaan pada sayatan paru menunjukkan adanya peningkatan respons kontraksi terhadap metakholin pada paru tikus tua berdasar pada besar dosis minimum, maksimum dan pergeseran kurva ke kiri pada gambar kurva dosis respons (Tabel 6 dan Gambar 2).

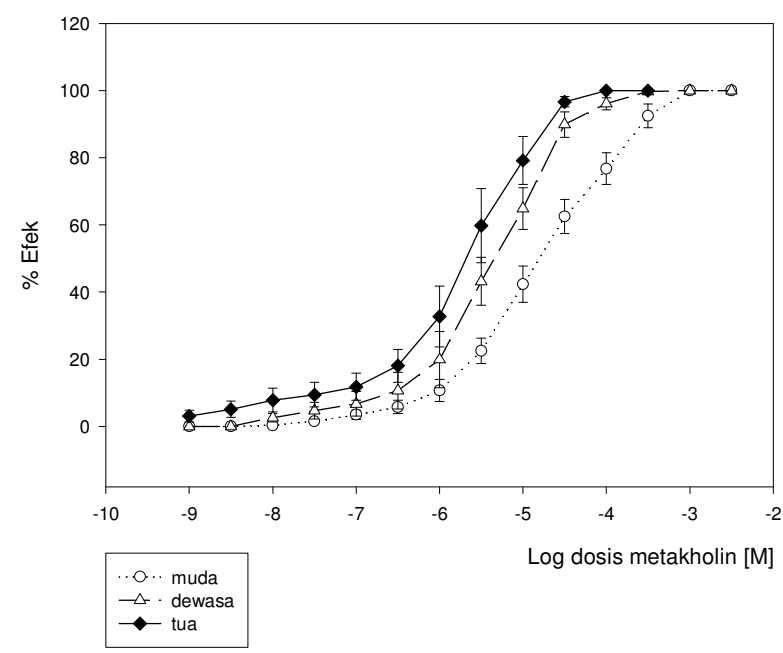

Keterangan:Pergeseran kurva sayatan paru tua ke kiri menunjukkan peningkatan respons sayatan paru tikus tua terhadap metakholin dibanding dewasa dan muda.

\section{Gambar 2.Kurva Dosis Respons metakholin pada sayatan paru tikus muda, dewasa dan tua.}

Uji statistik menunjukkan bahwa ED50 dan $\mathrm{pD}_{2}$ metakholin pada paru tikus tua lebih tinggi dari paru tikus muda secara bermakna $(p<0,05)$, sedang emaks dan tmaks tidak bermakna. Pada analisa korelasi didapatkan adanya hubungan linier dan bermakna $(r=0.53, p=0.02)$ antara peningkatan umur tikus dengan peningkatan $\mathrm{pd}_{2}$ metakholin di sayatan paru tikus (Tabel 8)

Tabel7. Rerata efek kontraksi maksimum, waktu maksimum, ED50 dan pD2 metakholin pada trakhea tikus muda, dewasa dan tua.

\begin{tabular}{lcccc}
\hline & $\begin{array}{c}\text { Muda } \\
(\mathrm{n}=8)\end{array}$ & $\begin{array}{c}\text { Dewasa } \\
(\mathrm{n}=8)\end{array}$ & $\begin{array}{c}\text { Tua } \\
(\mathrm{n}=8)\end{array}$ & sig \\
\hline Emaks & $12,85 \pm 1,37$ & $14,22 \pm 1,28$ & $16,8 \pm 2,06$ & 0,256 \\
Tmaks (mnt) & $22,5 \pm 1,5$ & $27,12 \pm 1,51$ & $26,62 \pm 1,72$ & 0,130 \\
ED50 [M] & $3,36.10^{-7} \pm 0,54.10^{-8}$ & $5,01.10^{-7} \pm 0,68.10^{-7}$ & $3,85.10^{-7} \pm 0,91.10^{-}$ & 0,286 \\
$\mathrm{pD}_{2}$ & $6,52 \pm 0,08$ & $6,33 \pm 0,06$ & 7 & 0,302 \\
& & & $6,52 \pm 0,12$ & \\
\hline
\end{tabular}

Tabel 8. Rerata efek kontraksi maksimum, waktu maksimum, ED50 dan $\mathrm{pD}_{2}$ metakholin pada sayatan paru tikus muda, dewasa dan tua.

\begin{tabular}{lcccc}
\hline & $\begin{array}{c}\text { Muda } \\
(\mathrm{n}=6)\end{array}$ & $\begin{array}{c}\text { Dewasa } \\
(\mathrm{n}=6)\end{array}$ & $\begin{array}{c}\text { Tua } \\
(\mathrm{n}=6)\end{array}$ & sig \\
\hline Emaks & $144,23 \pm 15,72$ & $114,3 \pm 22,25$ & $92,61 \pm 19,71$ & 0,247 \\
Tmaks (mnt) & $28 \pm 1,12$ & $27,5 \pm 1,43$ & $25,5 \pm 2,52$ & 0,918 \\
ED50 [M] & $9,97.10^{-6} \pm 2,65.10^{-6}$ & $4,98.10^{-6} \pm 0,93.10^{-6}$ & $3,01.10^{-6^{*} \pm 0,95.10^{-6}}$ & 0,032 \\
$\mathrm{pD}_{2}$ & $5,05 \pm 0,08$ & $5,41 \pm 0,16$ & $5,70^{*} \pm 0,18$ & \\
& & & & 0,046 \\
& & & & $(\mathrm{r}=0,53)$ \\
\hline
\end{tabular}




\section{DISKUSI}

Dari uraian hasil di atas dapat diketahui bahwa terjadi penurunan respons relaksasi trakhea dan paru terhadap stimuli agonis reseptor adrenergik- $\beta$ (isoprenalin) pada tikus tua dibanding dewasa dan muda. Penurunan respons ini digambarkan oleh besar dosis minimum dan maksimum yang lebih tinggi dibutuhkan oleh tikus tua (Tabel 1 dan 3) dan adanya pergeseran kurva tikus tua ke kanan pada gambar "kurva dosis respons" isoprenalin (Gambar 1). Selain itu didapatkan penurunan kepekaan (ED50) dan afinitas $\left(\mathrm{pD}_{2}\right)$ reseptor adrenergik- $\beta$ terhadap isoprenalin pada trakhea dan paru tikus tua dibanding dewasa dan muda secara bermakna $(p<0,05)$, sedangkan antara dewasa dan muda penurunan ini tidak bermakna. Analisa korelasi menunjukkan adanya hubungan linier yang signifikan antara peningkatan umur dengan peningkatan ED50 dan penurunan $\mathrm{pD}_{2}$, isoprenalin $(r=-0,81 ; p=0,00)$. Data kuantitatif lain ditunjukkan oleh Emaks dan Tmaks, yaitu terdapat penurunan Emaks dan perpanjangan waktu Tmaks baik pada trakhea maupun pada sayatan paru tikus tua dibanding dewasa dan muda, tetapi data ini tidak bermakna kecuali pada perpanjangan Tmaks trakhea tua. Dari data Emaks dan Tmaks ini menggambarkan adanya hambatan pada mekanisme sinyal transduksi pada trakhea dan paru tikus tua.

Perbedaan yang tidak bermakna antara umur muda dengan dewasa baik di trakhea maupun sayatan paru tikus dikarenakan pada proses tumbuh kembang saluran nafas dan paru sudah berfungsi sejak dilahirkan (19), bahkan reseptor adrenergik- $\beta$ sudah berespons relaksasi terhadap isoprenalin sejak fetus (20). Perbedaan bermakna yang terjadi pada umur tua dikarenakan adanya perubahan fungsional / fisiologis pada penuaan.

Efek relaksasi isoprenalin pada trakhea dan paru tikus dapat terjadi melalui stimuli pada reseptor adrenergik$\beta_{1}$ dan $\beta_{2}$ yang tersebar di seluruh saluran nafas, selanjutnya ikatan dengan reseptor ini mengawali mekanisme sinyal transduksi. Mula-mula terjadi penggabungan (coupling) reseptor dan protein Gs dan berikutnya Gsa-GTP mengaktifkan adenilat siklase untuk mengkatalisa pembentukan CAMP dari ATP. C-AMP yang terbentuk mengaktifkan protein kinase $A(P K A)$ untuk memfosforilasi berbagai protein intraseluler dan menimbulkan efek relaksasi otot polos saluran nafas. Peran PKA antara lain memfosforilasi MLCK (myosin light chain kinase) sehingga aktivitas MLCK memfosforilasi myosin menurun dan terjadi pengurangan sensitivitas terhadap $\mathrm{Ca}++/$ calmodulin, juga memfosforilasi kanal-kanal ion sehingga terjadi aktivasi kanal $\mathrm{KCa}$, hiperpolarisasi membran sel otot polos dan meningkatkan reuptake $\mathrm{Ca}^{++}(17,20,21)$. Berdasar mekanisme isoprenalin tersebut, maka jika terjadi penurunan respons relaksasi otot polos saluran nafas seperti pada percobaan ini kemungkinan karena adanya perubahan pada reseptor transmembran, mekanisme sinyal transduksi yang meliputi protein Gs, adenilat siklase, cAMP, protein kinase $\mathrm{A}$, atau pada distal dari protein kinase (misal protein kontraktil).

Pada penuaan telah dibuktikan bahwa kadar NE plasma meningkat yang diduga karena peningkatan aktivitas simpatis $(6,11,22)$. Peningkatan NE selama proses penuaan menyebabkan regulasi reseptor berupa desensitisasi reseptor adrenergik- $\beta$ di jantung dengan mekanisme khusus yang berbeda dari paparan NE kronik ataupun gagal jantung $(6,7,8)$. Analog dengan di jantung maka peningkatan NE plasma juga dapat menyebabkan paparan NE ke reseptor di saluran nafas yang terus menerus selama proses penuaan sehingga terjadi regulasi reseptor berupa desensitisasi reseptor adrenergik- $\beta$ di trakhea dan paru. Desensitisasi akibat regulasi homolog terjadi karena munculnya $\beta A R K i n a s e$ yang memfosforilasi reseptor menjadi tidak aktif $(3,18)$. Selain itu peningkatan lipid peroksid di membran sel pada umur tua akan menghambat coupling protein- $G$ dengan reseptor sehingga sinyal transduksi terhambat. (16). Studi lain melaporkan bahwa mediator inflamasi IL- $\beta$ dan TNF-a dan mediator inflamasi lainnya dapat menimbulkan regulasi heterolog (cross-talk) dengan reseptor adrenergik- $\beta$. Berbagai mediator ini terbukti menurunkan respons reseptor adrenergik- $\beta$ di otot polos saluran nafas $(15,23,24)$. Pada penuaan, saluran nafas merupakan organ yang sering mengalami inflamasi sehingga mekanisme regulasi heterolog (cross-talk) dapat terjadi dan mengakibatkan penurunan respons reseptor adrenergik- $\beta$.

Dengan demikian pada penelitian ini dapat disimpulkan bahwa penurunan respons relaksasi trakhea dan paru tikus tua terhadap stimulasi isoprenalin yang dibuktikan dengan penurunan kepekaan dan afinitas reseptor adrenergik- $\beta$ kemungkinan disebabkan hambatan sinyal transduksi dan melalui mekanisme regulasi homolog dan heterolog berupa desensitisasi reseptor adrenergik- $\beta$ di trakhea dan paru.

Hasil percobaan dengan menggunakan metakholin pada trakhea didapatkan bahwa secara kualitatif terjadi peningkatan respons kontraksi terhadap metakholin pada trakhea tikus tua dibanding dewasa. Secara kuantitatif peningkatan respons kontraksi ini tidak bermakna (dari penghitungan ED50 dan pD2). Hasil percobaan tersebut didukung oleh penemuan Preuss (1999) bahwa pada penuaan tidak didapatkan perubahan yang bermakna dari respons trakhea (isolated) tikus terhadap asetilkholin. Pengukuran kadar inositol fosfat terhadap stimulasi asetilkholin juga tidak berubah pada tikus tua walaupun pada marmut tua terjadi penurunan (25).

Hasil percobaan pada sayatan paru menunjukkan adanya peningkatan respons kontraksi terhadap metakholin pada paru tikus tua berdasar pada besar dosis minimum, maksimum dan pergeseran kurva ke kiri pada gambar kurva dosis respons (Tabel 6 dan Gambar 2). Uji statistik menunjukkan bahwa ED50 dan $\mathrm{pD}_{2}$ metakholin pada paru tikus tua 
lebih tinggi dari paru tikus muda secara bermakna $(p<0,05)$, sedang Emaks dan Tmaks tidak bermakna. Pada analisa korelasi didapatkan adanya hubungan linier dan bermakna $(r=0.53, p=0.02)$ antara peningkatan umur tikus dengan peningkatan $\mathrm{pD}_{2}$ metakholin di sayatan paru tikus.

Dari uraian di atas tentang hasil percobaan respons trakhea dan paru terhadap metakholin, dapat disimpulkan bahwa terjadi peningkatan respons kontraksi trakhea dan paru tikus tua terhadap stimuli agonis reseptor muskarinik (metakholin), kepekaan dan afinitas (pD2) reseptor muskarinik terhadap agonis meningkat pada paru tua tetapi tidak pada trakhea tikus tua, dan besar Emaks serta Tmaks tidak menunjukkan perbedaan yang bermakna.

Efek kontraksi metakholin pada trakhea dan sayatan paru tikus dapat terjadi terutama melalui stimuli pada reseptor muskarinik $M_{3}$ saluran nafas. Selain itu di saluran nafas juga didapatkan sub tipe reseptor muskarinik $M_{1}, M_{2}$ presinap dan pos-sinap. Efek kontraksi pada sayatan paru melalui stimuli pada reseptor muskarinik $M_{1}$ yang terletak di ganglion otonomik, $\mathrm{M}_{2}$ dan $\mathrm{M}_{3}$ di otot polos bronkhioli, kelenjar sub mukosa dan epitehelium. Namun dari studi sebelumnya telah dibuktikan bahwa kontraksi pada sayatan paru tikus ini terutama diperantarai oleh reseptor muskarinik $\mathrm{M}_{3}$ (26). Secara garis besar mekanisme stimulasi pada reseptor muskarinik $\mathrm{M}_{3}$ ini dimulai dengan ikatan metakholin dengan reseptor yang akan mengaktifkan phospholipase $C$ (PLC) melalui penggabungan dengan protein $\mathrm{Gq}$ untuk menghidrolisa phospatidylinositol 4,5-biphosphat (PIP2). Hasil hidrolisa adalah terbentuk dua second messenger inositol 1,4,5-triphosphat (IP3) dan diacylglycerol (DAG), IP3 mengawali kontraksi dengan memobilisasi $\mathrm{Ca}++$ intrasel dan DAG mempertahankan kontraksi melalui aktivasi protein kinase $C(P K C)$ yang meningkatkan afinitas elemen kontraktil terhadap Ca++ dan terjadi kontraksi $(17,26)$. Sedangkan mekanisme kontraksi melalui reseptor muskarinik $\mathrm{M}_{2}$ diawali dengan ikatan agonis dengan reseptor, selanjutnya melalui protein $\mathrm{Gi}$ (inhibitor) menghambat aktivitas adenilat siklase sehingga pembentukan cAMP berkurang dan relaksasi berkurang maka secara fungsional terjadi peningkatan kontraksi (26). Berdasar mekanisme metakholin tersebut, maka jika terjadi peningkatan respons kontraksi otot polos saluran nafas tehadap metakholin seperti pada percobaan ini kemungkinan karena adanya perubahan pada tingkat reseptor, mekanisme sinyal transduksi dan/ atau pada protein kontraktil.

Pada umur tua terjadi penurunan fungsi saraf vagus yaitu penurunan kecepatan konduksi saraf karena penipisan lapisan myelin dan berkurangnya refleks otonom (27). Penurunan aktivitas parasimpatis dan konduksi saraf vagus pada umur tua mengakibatkan pengeluaran asetilkholin dari ujung saraf berkurang, sehingga reseptor muskarinik $M_{2}$ dan $M_{3}$ saluran nafas mengalami kekosongan atau seperti pemberian antagonis reseptor. Jika keadaan seperti ini ber- langsung terus menerus selama proses penuaan maka kemungkinan akan terjadi mekanisme regulasi berupa supersensitsasi.

Bertolak dari uraian tersebut di atas, maka dapat disimpulkan bahwa pada sayatan paru tikus tua terjadi peningkatan respons kontraksi terhadap stimuli metakholin yang disebabkan karena peningkatan kepekaan dan afinitas reseptor muskarinik melalui mekanisme supersensitisasi. Perubahan ini tidak disertai perubahan pada besar Emaks dan Tmaks. Supersensitivitas reseptor muskarinik selain karena regulasi homolog di reseptor transmembran, mungkin juga karena regulasi heterolog melalui mekanisme cross-talk saat proses transduksi sinyal.

Dari percobaan yang dilakukan, terbukti bahwa pada penuaan terjadi penurunan respons reseptor adrenergik- $\beta$ yang disertai peningkatan respons reseptor muskarinik di trakhea dan sayatan paru tikus. Hanya saja peningkatan respons reseptor muskarinik di trakhea secara kuantitatif tidak bermakna. Sejauh ini diketahui bahwa ada interaksi sinyal transduksi antara reseptor adrenergik dan muskarinik melalui proses cross-talk. Dalam keadaan normal interaksi reseptor adrenergik- $\beta$ dengan reseptor muskarinik dapat terjadi secara timbal balik. Contohnya stimulasi agonis muskarinik pada reseptor muskarinik $\mathrm{M}_{2}$ akan mengaktivasi protein $\mathrm{Gi}$, dan selanjutnya menghambat aktivitas adenil siklase sehingga respons relaksasi otot polos menjadi menurun. Selain itu stimulasi agonis muskarinik pada reseptor muskarinik $M_{3}$ akan meningkatkan PKC yang menyebabkan down regulation dengan menekan ekspresi gen pada reseptor adrenergik- $\beta$ melalui MAP kinase. Sebaliknya stimuli pada reseptor adrenergik- $\beta$ yang meningkatkan c-AMP akan menghambat sinyal pada jalur $\operatorname{PLC}(17,20,26)$. Fakta lain menunjukkan pemberian agonis reseptor adrenergik- $\beta$ jangka lama secara homolog menekan reseptor adrenergik- $\beta$ tapi secara heterolog (melalui cross-talk) meningkatkan konsentrasi mRNA reseptor $\mathrm{M}_{2}$ pada jantung itik dan pada sel HEL299 (28) Interaksi biokimiawi pada cross-talk antara reseptor adrenergik- $\beta$ dengan reseptor muskarinik dapat menghasilkan efek stimulasi atau inhibisi tergantung pada homeostasis yang akan dicapai (18). Regulasi heterolog (cross-talk) juga terjadi antara reseptor adrenergik- $\beta$ dengan reseptor dari mediator inflamasi IL-1 $\beta$ dan TNF- $\alpha$, serta mediator inflamasi lainnya. Berbagai mediator ini terbukti menurunkan respons reseptor adrenergik- $\beta$ di otot polos saluran nafas dan meningkatkan fungsi dan ekspresi reseptor muskarinik di saluran nafas $(15,23,24,28)$

Reseptor adrenergik- $\beta_{2}$ mempunyai 2 jalur sinyal transduksi yaitu melalui protein $\mathrm{Gs}$ dan protein $\mathrm{Gq}(29)$. Di saluran nafas yang terbanyak adalah reseptor adrenergik- $\beta_{2}$ maka dapat diperkirakan pada penuaan yang terjadi hambatan pada jalur sinyal transduksi Gs-adenilsiklase-cAMPPKA, akan mengakibatkan jalur protein Gq menjadi lebih 
menonjol dan menjadi supersensitif terhadap rangsangan agonis reseptor yang menggunakan protein $\mathrm{Gq}$ seperti pada reseptor muskarinik.

Dari berbagai uraian di atas dapat diketahui bahwa ada hubungan antar reseptor adrenergik dan kholinergik melalui proses cross talk yang merupakan proses yang kompleks dan hasilnya tidak selalu sama tergantung sub tipe reseptor dan lokasi reseptor. Selain itu proses cross talk juga terjadi antar mediator dengan reseptor di saluran nafas. Secara keseluruhan mekanisme ini terjadi sebagai upaya untuk mempertahankan fungsi fisiologi suatu organ.

Bertolak dari telaah hasil percobaan, terbukti bahwa proses penuaan di saluran nafas tikus tidak saja terjadi penurunan respons reseptor adrenergik- $\beta$ namun disertai dengan peningkatan respons reseptor muskarinik khususnya di jaringan paru. Keadaan ini menunjukkan bahwa meningkatnya respons reseptor muskarinik sebagai upaya kompensasi terhadap menurunnya respons reseptor adrenergik- $\beta$ pada penuaan sehingga tercapai keseimbangan baru untuk mempertahankan fungsi fisiologis saluran nafas. Terjadinya upaya kompensasi ini melalui mekanisme cross talk karena adanya perubahan-perubahan pada proses penuaan di reseptor adrenergik- $\beta$ dan reseptor muskarinik serta melalui mediator inflamasi.

Mekanisme yang mendasari penurunan respons reseptor adrenergik- $\beta$ pada umur tua diduga disebabkan 1) hambatan pada mekanisme sinyal transduksi, 2) regulasi reseptor berupa desensitisasi reseptor baik homolog ataupun melalui proses cross talk terhadap reseptor dari mediator inflamasi selama proses penuaan. Sedang mekanisme yang mendasari peningkatan respons reseptor muskarinik diduga karena 1) regulasi berupa supersensitisasi reseptor, 2 ) melalui proses cross talk dengan reseptor adrenergik- $\beta$ dan dengan berbagai reseptor dari mediator inflamasi menimbulkan regulasi heterolog sehingga terjadi peningkatan kepekaan reseptor.

Penurunan respons reseptor adrenergik- $\beta$ di saluran nafas yang disertai meningkatnya respons reseptor muskarinik pada proses penuaan tidak terlepas dari perubahan sistim pernafasan secara keseluruhan. Meskipun demikian sistem respirasi mempunyai kemampuan yang luar biasa untuk beradaptasi baik struktur maupun fungsinya. Kemampuan adaptasi ini diperlukan agar fungsi transport oksigen tetap berjalan untuk menunjang fungsi respirasi yang adequat sepanjang masa hidupnya (30).

Dengan telah dibuktikan bahwa pada proses penuaan terjadi penurunan respons reseptor adrenergik- $\beta$ di trakhea dan sayatan paru, serta peningkatan respons reseptor muskarinik di sayatan paru, maka penggunaan klinik obatobat yang merangsang bronkhospasme dihindari pada usia lanjut karena adanya hiperaktivitas kholinergik. Demikian juga penggunaan obat agonis reseptor adrenergik- $\beta$ untuk asma bronkhiale pada usia lanjut harus diperhatikan dosisnya.

\section{KESIMPULAN}

1. Respons reseptor adrenergik- $\beta$ yang digambarkan oleh relaksasi trakhea dan sayatan paru terhadap isoprenalin semakin menurun seiring dengan pertambahan umur tikus (muda, dewasa, tua).

2. Respons reseptor muskarinik yang digambarkan oleh kontraksi trakhea dan sayatan paru terhadap metakholin meningkat pada tikus umur tua, terutama pada sayatan paru tikus tua.

3. Mekanisme yang mendasari perubahan respons reseptor adrenergik- $\beta$ dan muskarinik terhadap agonisnya pada saluran nafas tikus tua diduga melalui regulasi homolog dan heterolog (cross talk).

4. Penurunan respons reseptor adrenergik- $\beta$ yang disertai peningkatan respons reseptor muskarinik pada saluran nafas tikus tua merupakan upaya untuk mempertahankan fungsi fisiologis sehingga tercapai keseimbangan baru.

\section{SARAN}

1.Perlu dilakukan penelitian lanjutan tentang mekanisme regulasi yang menyebabkan perubahan struktur reseptor khususnya densitas reseptor dan perubahan pada tahapan sinyal transduksi pada proses penuaan.

2. Pada penelitian tentang respons obat harus diperhitungkan faktor umur dan kemungkinan adanya mekanisme cross talk antar reseptor baik pada binatang coba ataupun pada manusia.

3. Penggunaan klinik obat-obat bronkhodilator khususnya golongan agonis reseptor adrenergik- $\beta$ harus dipertimbangkan dosisnya pada usia lanjut

\section{DAFTAR KEPUSTAKAAN}

1. Cotran RS, Kumar V, Collins T. Cellular Pathology II: Adaptations, Intracellular Accumulations, and Cell Aging in Robbins Pathologic Basis of Disease, 6th ed. Philadelphia: W.B. Saunders; 1999; 31-49.

2. Nies Alan S \& Spielberg SP. Principles of therapeutics in Goodman \& Gilman's The Pharmacological Basis of Therapeutics ed.by Hardman Joel G, Limbird LE, Gilman Alfred G, $10^{\text {th }}$ ed. The McGraw-Hill Companies Inc 2001; 45-66.

3. Bourne Henry R \& Zastrow Mark von. Drug Receptor \& Pharmacodynamics in Basic And Clinical Pharmacology ed.by Katzung BG, $8^{\text {th }}$ ed. USA: Apleton \& Lange; 2001; 9-34.

4. Barnhill JG, Greenblatt DJ, Miller LG, Gaver A, Harmatz JS, Shader RI. Kinetic and dynamic components of increased benzodiazepine sensitivity in aging animals. J-Pharmacol- Exp-Ther. 1990; Jun, 253(3): 1153-1161. 
5. Setyawati SK. Hubungan Proses Penuaan Dengan Efek Antagonis Reseptor Histamin H1 Pada Sistem Saraf Pusat Tikus Dan Ileum Marmut . [Tesis S-2]. Surabaya: Universitas Airlangga.1993.

6. Miyamoto Atsushi \& Oshika Hideyo. Cellular and Molecular Mechanisms of Cardiovascular Aging: Molecular Pharmacological Implications in Pharmacological Intervention in Aging and Age-Associated Disorders, Annals New York Academy of Science, vol.786, edited by Kitani K. New York: The New York Academy of Science; 1996; 283-293.

7. Xiao Rui-Ping. Age associated Reductions in Cardiac $\beta 1$-and $\beta 2$-adrenergic Response without Changes in Inhibitory $G$ Proteins or Receptor Kinases. J. Clin.Invest. 1998; 101 (6): 1273-1282.

8. Brodde OE \& Michel M. Adrenergic and Muscarinic Receptors in the Human Heart. Pharmacological Reviews. 1999; 51(4): 651-689.

9. Fujii Koji . Impaired Isoproterenol-Induced Hyperpolarization in Isolated Mesenteric Arteries of Aged Rats. Hypertension. 1999; 34: 222-228.

10. Borst SE, Narang N, Crews FT, Scarpace PJ. Reduced alpha 1-adrenergic receptor-mediated inostide hydrolysis in cardiac atria of senescent rats. J-Cardiovasc-Pharmacol. 1990; Sep: 16(3): 444-448.

11. Docherty JR. Effects of Aging on Prejunctional Control of Neurotransmission in the Rat in Pharmacological Intervention in Aging and Age-Associated Disorders, Annals New York Academy of Science, vol.786, edited by Kitani K. New York: The New York Academy of Science, 1996; 264-273.

12. Brodde OE. Cardiac Muscarinic Receptors Decrease with Age. J. Clin.Invest. 1998; 101(2): 471-478.

13. Lithgow Gordon J. and Kirkwood Thomas BL. Mechanisms and Evolution of Aging. Science, 1996; vol.273, 5 Juli: 80.

14. Yu Pal Byung and Yang Ryung. Critical Evaluation of the Free Radical Theory of aging: A Proposal for the Oxidative Stress Hypothesis in Pharmacological Intervention in Aging and Age-Associated Disorders. Annals New York Academy of Science, vol.786, edited by Kitani K et al. New York: The New York Academy of Science; 1996: 1-11.

15. Hakonarson H, Herrick DJ, Serrano PG, and Grunstein MM. Mechanism of Cytokine-induced Modulation of $\beta$ adrenoceptor responsivness in Airway Smooth Muscle. J. Clin.Invest.1996; 97 (11): 2593-2600.

16. Halliwell B and Gutteridge JM. Free Radicals in Biology and Medicine, Clarendon Press, Oxford. 1999.

17. Hall IP. Second messengers, ion channels and pharmacology of airway smooth muscle (Series "The Airway Smooth Muscle Cell"), Eur Respir J. 2000; 15; 1120-1127.

18. Ross Elliot M \& Kenaki Terry P. Pharmacodynamics; Mechanism of Drug Action and The Relationship Between Drug Concentration and Effect in Goodman \& Gilman's The Pharmacological Basis of Therapeutics ed.by Hardman Joel G, Limbird LE, Gilman Alfred G, $10^{\text {th }}$ ed. The McGraw-Hill Companies Inc. 2001; 31-44.

19. Wirtz HR. \& Dobbs LG. The effects of mechanical forces on lung functions. Respiration Physiology. 2000; 119: 1-17.

20. Anderson Gary P. Adrenaline and Noradrenaline in Airways Smooth Muscle: Neurotransmitters, Amines, Lipid Mediators and Signal Transduction ed. By Raeburn D \& Giembycz MA, Birkhauser Verlag Basel, Switzerland 1995; 1-80.

21. Kotlikoff Michael I \& Kamm Kristne E. Molecular mechanisms of $\beta$-adrenergic relaxation of airway smooth muscle. Annu.Rev.Physiol. 1996; 58:115-141.

22. Petrie Eric C. Increase Plasma Norepinephrine e to Yohimbine in Elderly Men. Journal of Gerontology: MEDICAL SCIENCES 2000; 55A (3): M155-M159.

23. Mardini Issam A. Functional Behavior of the B-Adrenergic Receptor-Adenylyl Cyclase System in Rabbit Airway Epitheliium. Am.J.Respir.Cell Mol.Biol. 1994; vol.11: 287-295.

24. Pang L, Holland E \& Knox AJ. Impaired cAMP production in human airway smooth muscle cells by bradykinin: role of cyclooxygenase products. Am.J.Physiol. 1998; .275 (Lung Cell.Mol.Physiol.19): L322-L329.

25. Preuss JMH \& Goldie RG. Age-related changes in muscarinic cholinoceptor function in guinea-pig and rat airways (abstract). 1999. http://athene.em.springer.de/cgil diakses pada 6 April 2001.

26. Roffel AF \& Zaagsma J. Acetylcholine in Airways Smooth Muscle: Neurotransmitters, Amines, Lipid Mediators and Signal Transduction ed. By Raeburn D \& Giembycz MA. Switzerland: Birkhauser Verlag Basel; 1995; 81-130.

27. Melcangi RC, Magnaghi V, Martini L. Aging in peripheral nerves: regulation of myelin protein genes by steroid hormones. Progress in Neurobiology. 2000; 60: 291-308.

28. Haddad El-Bdaoui \& Rousell J. Regulation of the expression and function of the M2 muscarinic receptor, Trends Pharmacol.Sci., August. 1998; vol.19: 322-327.

29. Dzimiri Nduna, Regulation of $\beta$-Adrenoceptor Signaling in Cardiac Function and Disease Pharmacological Reviews, 1999; 51(3): 465-497.

30. Takubo Y. Age-associated changes in elastin and collagen content and the proportion of types I and III collagen in the lung of mice, Experimental Gerontology. 1999; 34: 353-364. 